INDONESIAN JOURNAL OF

Clinical Pathology and Medical Laboratory

Majalah Patologi Klinik Indonesia dan Laboratorium Medik

\begin{tabular}{|c|c|c|c|c|c|}
\hline $\begin{array}{c}\text { IJCP \& ML } \\
\begin{array}{c}\text { (Maj. Pat. Klin. } \\
\text { Indonesia \& Lab. Med.) }\end{array}\end{array}$ & Vol. 17 & No. 3 & Hal. 127-177 & $\begin{array}{c}\text { Surabaya } \\
\text { Juli 2011 }\end{array}$ & $\begin{array}{c}\text { ISSN } \\
0854-4263\end{array}$ \\
\hline
\end{tabular}

Diterbitkan oleh Perhimpunan Dokter Spesialis Patologi Klinik Indonesia

Published by Indonesian Association of Clinical Pathologists

Terakreditasi No: 43/DIKTI/Kep/2008, Tanggal 8 Juli 2008 


\section{INDONESIAN JOURNAL OF \\ CLINICAL PATHOLOGY AND MEDICAL LABORATORY \\ Majalah Patologi Klinik Indonesia dan Laboratorium Medik}

\section{DAFTAR ISI}

\section{PENELITIAN}

Creatine Kinase Myocardial Band, Myeloperoxidase, Matrix Metalloproteinase- 9 dan Troponin T Pada IMA

(The Creatine Kinase Myocardial Band, Myeloperoxidase, Matrix Metalloproteinase-9 Activities and Troponin $T$ in Myocardial Infarction)

IA Hutagalung, I Patellongi, R Pakasi, M Arif, AA Mappahya, Hardjoeno

D-Dimer Penderita Sindrom Koroner Akut dan Stenosis

(D-Dimer in Acute Coronary Syndrome and Stenosis)

Birhasani, Lisyani BS, Ria T

Uji Hematologi Pasien Terduga Demam Berdarah Dengue Indikasi Rawat Inap

(Hematology Test of Dengue Hemorrhagic Fever on Suspected Patients Indicated for Hospitalization) Juranah, Darwati Muhadi, Mansyur Arif, Burhanuddin Bahar .

Imunokimiawi PGE2 Usus Ileum yang Kekurangan Energi Protein

(Immunohistochemistry of PGE2 Ileum Intestine Protein Energy Deficiency)

R. Heru Prasetyo

Gamma-glutamyltransferase dan Apolipoprotein B dengan Sindroma Metabolik

(Gamma-glutamyltransferase and Apolipoprotein B with the Metabolic Syndrome)

Tahono, M.I. Diah Pramudianti.

146-150

Umbi Ubi Jalar Ungu Bali (Ipomoea batatas) di Transaminase Serum, Malondialdehide Hepar dan Alkohol Kronis

(Balinese Purple Sweet Potato (Ipomoea batatas L) on SGOT, SGPT, MDA level and Chronic Alcohol) I Wayan Putu Sutirta-Yasa, I Made Jawi, Ida Bagus Ngurah, Anak Agung Ngurah Subawa.

Leukosit Infeksi Bakteri Sistemik

(Leucocyte in Systemic Bacterial Infections)

Meita Hendrianingtyas, MI. Tjahjati DM

Meningitis Tuberculosis

(Meningitis Tuberculosis)

Silvia Rachmayati, Ida Parwati, A Rizal, D Oktavia

Platelet Aggregation In Acute Coronary Syndrome

(Aggregasi Trombosit di Sindroma Koroner Akut)

Sulianty, Adi K Aman.

TELAAH PUSTAKA

Pemetaan Epitop dan Aplikasi Klinisnya

(Epitope Mapping and It's Clinical Aplication)

Jusak Nugraha.

LAPORAN KASUS

Infeksi Virus Rabies di Anak-anak

(Rabies Virus Infection in Children)

A.A.N. Subawa, DGD. Dharma Santhi, A.A Raka Sudewi, IWP. Sutirta Yasa 


\title{
PLATELET AGGREGATION IN ACUTE CORONARY SYNDROME
}

\author{
(Aggregasi Trombosit di Sindroma Koroner Akut)
}

\author{
Sulianty, Adi K Aman
}

\begin{abstract}
Haemostatic system is the mechanism that controls response of bleeding or thrombosis, so that thrombogenesis and fibrinolysis are in balance. Obstruction of brain and heart vascular system often occurred, because of the hyperactivity of thromboses function that causes thrombosis. $C B C$, blood glucose, lipid profile and cardiac enzyme assay were performed on acute coronary syndrome patients at the Emergency Department as well as at the normal control. In this study, each group consist of 10 patients. Platelet aggregation test was measured with turbidimetric method using Helena Agram aggregometer. ADP and epinephrine 5 and $10 \mu M$ were used as the agonists. There was significant difference in the mean total cholesterol, LDL and blood sugar level in the acute coronary syndrome patients than the control group. Platelet aggregations with $A D P 1$ and $5 \mu M$ were significantly different in the acute coronary syndrome patients than the control one. In this study were found patients aged above 50 years old=have platelet aggregation with ADP $10 \mu M$, which differ significantly than the control group.
\end{abstract}

Key words: Platelet aggregation, acute coronary syndrome

\begin{abstract}
ABSTRAK
Sistem hemostasis merupakan mekanisme tubuh dalam mengontrol respons terhadap perdarahan atau terjadinya trombosis yang berlebihan, sehingga pembentukan trombus (trombogenesis) dan penguraian fibrin (fibrinolisis) dalam keadaan seimbang. Penyumbatan pembuluh darah otak dan jantung sering terjadi akibat kegiatan lebih fungsi trombosit yang menimbulkan trombosis. Pemeriksaan yang dilakukan adalah: darah rutin, gula darah, gambaran/profil lipid dan enzim jantung di 10 orang pasien sindroma koroner akut di IGD dan 10 orang normal sebagai pembanding. Pemeriksaan agregasi trombosit dengan cara turbidimetri memakai agregometer Helena Agram, dengan memakai penggerak utama (agonist) ADP, epinefrin 5 dan $10 \mu$ M. Perbedaan bermakna yang dijumpai berkadar rerata dalam jumlah keseluruhan: kolesterol, LDL dan gula darah di kelompok pasien SKA dibandingkan dengan kelompok pembanding. Agregasi trombosit dengan agonist ADP 1 dan $5 \mu \mathrm{M}$ berbeda bermakna di kelompok pasien SKA dibandingkan dengan kelompok pembanding. Di pasien SKA yang berusia di atas 50 tahun, agregasi trombosit dengan agonist ADP $10 \mu \mathrm{M}$ berbeda bermakna dibandingkan dengan pembanding.
\end{abstract}

Kata kunci: Agregasi trombosit, sindroma koroner akut

\section{INTRODUCTION}

Hemostatic system is the mechanism that control bleeding and coagulation, so that coagulation and fibrinolysis are in balance. The role of thrombosis in haemostatic is to make the thrombosis plug, that start from platelet adhesion, shape change, granule secretion, aggregation and finally the activation of coagulation cascade by the thrombosis membrane. ${ }^{1-5}$

The acute coronary syndrome (ACS) consists of unstable angina pectoris (UAP), ST Elevation in Myocardial Infarct (STEMI) and Non ST Elevation Myocardial Infarct (NSTEMI). This acute coronary syndrome basic of atherosclerosis cause the formation of atheroma plaque.6,7 The obstruction of brain and heart vascularization often occur because of the thrombosis function hyperactivity, that cause thrombosis. Platelet aggregation test is performed to know the platelet function, most often carried out by the analyzer using a turbidimeter method (change by light transmission)..$^{8-10}$

The objective of this study is to know platelet aggregation function in an acute coronary syndrome.

\section{METHODS}

\section{The Study Population}

This study is carried out by a cross sectional method. There were included ten acute coronary syndrome patients ( 1 woman and 9 men) at the Emergency Department and ten normal persons were chosen for control, and were examined from October until December 2010. The diagnosis of acute coronary syndrome is established by a cardiologist from the patient's clinical symptoms, ECG specific for acute coronary syndrome and cardiac enzymes. Exclusion criteria are: patients who consum anti thrombosis 
Table 1. The characteristic of 2 (two) subject groups

\begin{tabular}{llll}
\hline \multicolumn{1}{c}{ Characteristic } & ACS $(\mathbf{N}=\mathbf{1 0})$ & Control $(\mathbf{N}=\mathbf{1 1})$ & $\mathbf{p}$ \\
\hline Sex & $9(90 \%)$ & $9(81.8 \%)$ & $\mathrm{p}>0.05$ \\
Male & $1(10 \%)$ & $2(18.2 \%)$ & $\mathrm{p}>0.05$ \\
Female & $53.6 \pm 10.48$ & $51 \pm 7.49$ & $\mathrm{p}>0.05$ \\
\hline Age (years) & $269.9 \pm 63.23$ & $285 \pm 85.95$ & $\mathrm{p}<0.05^{*}$ \\
\hline Thrombosis $\left(10^{3} \mathrm{sel} / \mathrm{mm}^{3}\right)$ & $200 \pm 45$ & $155 \pm 22.28$ & $\mathrm{p}>0.05$ \\
Total Cholesterol $(\mathrm{mg} / \mathrm{dL})$ & $150.3 \pm 67.5$ & $105.18 \pm 30.97$ & $\mathrm{p}>0.05$ \\
Triglyceride $(\mathrm{mg} / \mathrm{dL})$ & $36 \pm 8.7$ & $37.3 \pm 8.31$ & $\mathrm{p}<0.05^{*}$ \\
HDL (mg/dL) & $134.6 \pm 44.5$ & $98.27 \pm 17.03$ & $\mathrm{p}<0.05^{*}$ \\
LDL (mg/dL) & $182.6 \pm 96.79$ & $87.09 \pm 12.86$ & \\
Adr glucose $(\mathrm{mg} / \mathrm{dl})$ & & & \\
\hline
\end{tabular}

Note: * significant

drugs, NSAID and hormonal contraception, history of hereditary bleeding disturbance, chronic renal failure and dyslipidemia.

\section{The Biochemical Analysis}

The patient's blood were drawn into EDTA (Etilen Diamine Tetra-acetic Acid) tube for CBC (Complete Blood Count), 4 (four) silicone treated glass tubes with $3.6 \mathrm{~mL}$ of its volume with natrium citrate $3.8 \%$ to obtain platelet rich plasma (PRP) and platelet poor plasma (PPP) and $3 \mathrm{ml}$ blood without anticoagulant to obtain serum for lipid profile, cardiac enzyme and blood glucose assay.

CBC is performed with an automated analyzer Celldyne 3700 , to obtain the haematoloical profile. The lipid profile, CK-MB and blood glucose level are assayed enzymatically by an automated analyzer Hitachi 902, to obtain the risk factors of the acute coronary syndrome. Troponin $\mathrm{T}$ is performed with sandwich method using Roche Cardiac analyzer.

Citrate tube is centrifuged at $100 \mathrm{~g}$ for 5 minutes to obtain Platelet Rich Plasma (PRP). The plasma is then centrifuged again at 1600-2000 $\mathrm{g}$ for 10 minutes to obtain Platelet Poor Plasma (PPP). Platelet aggregation test is done by a turbidimetric method using Helena Agram aggregometer. For the agonist are used ADP 1.5 and $10 \mu \mathrm{M}$ and epinephrine 5 and $10 \mu \mathrm{M}$. Platelet aggregation test is done immediately after the PRP and PPP are obtained. As the platelets aggregate, and the light transmittance increase, they were measured in 10 minutes until the maximal platelet aggregation exist.

\section{Statistical Analysis}

The characteristic of the two groups is described in Table 1. which compare platelet aggregation induced by ADP and epinephrine in the acute coronary syndrome patients and normal control group. The independent $t$ test is used for the comparison between the two groups if the data is normally distributed. While the Mann-Whitney test is used for the comparison of variables with an abnormal distribution. The significanly used in the analysis if $\mathrm{p}<0.05$.

\section{THE RESULT AND DISCUSSION}

In this study, were obtained 16 acute coronary syndrome patients, but 6 (six) of them were excluded and 10 normal people included as the control group.

In this study, the mean total cholesterol level, LDL and at random glucose level differ significantly between the acute coronary syndrome patients and the control group.

Table 2. The 2 (two) groups platelet aggregation induced by ADP

\begin{tabular}{lccc}
\hline $\begin{array}{c}\text { Agonist } \\
(\boldsymbol{\mu M})\end{array}$ & $\begin{array}{c}\text { ACS patients } \\
(\mathbf{n}=\mathbf{1 0})\end{array}$ & $\begin{array}{c}\text { Control } \\
(\mathbf{n}=\mathbf{1 1})\end{array}$ & $\mathbf{p}$ \\
\hline ADP 1 & $17.16 \pm 13.72$ & $4.3 \pm 2.83$ & $\mathrm{p}<0.05^{*}$ \\
ADP 5 & $50.34 \pm 17.01$ & $34.84 \pm 17.79$ & $\mathrm{p}<0.05^{*}$ \\
ADP 10 & $75.43 \pm 22.34$ & $72.64 \pm 13.11$ & $\mathrm{p}>0.05$ \\
\hline
\end{tabular}

Note: * significant

In this study, the platelet aggregation induced by ADP 1 and $5 \mu \mathrm{M}$ differs significantly between the acute coronary syndrome patients and the control group.

Table 3. The 2 (two) groups platelet aggregation induced by Epinephrine

\begin{tabular}{lccc}
\hline $\begin{array}{c}\text { Agonist } \\
(\boldsymbol{\mu M})\end{array}$ & $\begin{array}{c}\text { ACS patients } \\
(\mathbf{n}=\mathbf{1 0})\end{array}$ & $\begin{array}{c}\text { Control } \\
(\mathbf{n}=\mathbf{1 1})\end{array}$ & $\mathbf{p}$ \\
\hline EPI 5 & $81.55 \pm 27.09$ & $72.13 \pm 15.42$ & $\mathrm{p}>0.05$ \\
EPI 10 & $87.16 \pm 48.32$ & $77.12 \pm 10.85$ & $\mathrm{p}>0.05$ \\
\hline
\end{tabular}

In this study, between the acute coronary syndrome patients and the control group there is no significant difference observed in the platelet aggregation which induced by epinephrine 5 and $10 \mu \mathrm{M}$. There is also no significant difference in the platelet aggregation induced by either ADP or epinephrine in the acute coronary syndrome patients with and without 
dyslipidemia, hypertension as well as those suffer diabetes mellitus. But there is a significant difference in the platelet aggregation induced by ADP $10 \mu \mathrm{M}$ in the acute coronary syndrome patients aged above 50 years old (Table 4).

Table 4. patients aged $<50$ years and $>50$ years platelet aggregation

\begin{tabular}{llll}
\hline Agonist & $\begin{array}{c}<\mathbf{5 0} \text { years } \\
(\mathbf{n}=\mathbf{3})\end{array}$ & $\begin{array}{c}>\mathbf{5 0} \text { years } \\
(\mathbf{n}=\mathbf{7})\end{array}$ & \multicolumn{1}{c}{$\mathbf{p}$} \\
\hline ADP 1 & $13.81 \pm 16.94$ & $8.34 \pm 6.36$ & $\mathrm{p}>0.05$ \\
ADP 5 & $48.61 \pm 21.99$ & $38.29 \pm 16.11$ & $\mathrm{p}>0.05$ \\
ADP 10 & $82.1 \pm 17.91$ & $65.12 \pm 14.62$ & $\mathrm{p}<0.05^{*}$ \\
EPI 5 & $86.56 \pm 25.12$ & $70.5 \pm 17.68$ & $\mathrm{p}>0.05$ \\
EPI 10 & $96.11 \pm 51.17$ & $73.15 \pm 12.18$ & $\mathrm{p}>0.05$ \\
\hline
\end{tabular}

Note: * significant

In this study, is observed an increase in platelet aggregation with ADP and epinephrine in the acute coronary syndrome group, but this test is performed only once. No significant difference is found between dyslipidemia, hypertension, diabetes mellitus patients and the increase in the platelet aggregation case. There is a significant difference in the platelet aggregation induced by ADP $10 \mu \mathrm{M}$ in patients aged above 50 years old. This is similar with the study carried out by Mardiana, which found significant increase in the platelet aggregation induced by ADP 5 and $10 \mu \mathrm{M}$ in UAP patients. ${ }^{11}$ Yoshida found that in UAP patients, the platelet aggregation induced by $\mathrm{ADP}$ and the collagen in resting condition is lower than the control group, but it is increased after they exercise. ${ }^{12}$

Guha et all performed platelet aggregation test on patients which suffer acute coronary syndrome within 48 hours and 7 days after treatment with aspirin and clopidogrel. The platelet aggregation induced by epinephrine, ADP and collagen were higher at 48 hours after treatment, and higher in diabetic and smoker group. ${ }^{13}$

Hutajulu found that platelet aggregation was higher at the first day and decreased after 7 days, although still higher than the control group. The location of infarct and smoking habit didn't affect the increase in platelet aggregation. ${ }^{14}$

Lakhey found significant increase in the platelet aggregation induced by all agonists (ADP, epinephrine, collagen and thrombin) in myocardial infarct and angina patients. Aspirin consumption is associated with the decrease of platelet response. The highest incidence of myocardial infarct are found among 45-54 years old. ${ }^{15}$

\section{CONCLUSION}

From this study, in the acute coronary syndrome patients compared to the control group the researchers found a significant increase in the platelet aggregation response induced by ADP 1 and $5 \mu \mathrm{M}$. There was also found a significant increase in the platelet aggregation response induced by ADP $10 \mu \mathrm{M}$ in patients aged above 50 years old.

\section{REFERENCES}

1. Tambunan KL. Patogenesis Trombosis. In: Sudoyo AW, Setiyohadi B, Alwi I, dkk. Ed. Buku Ajar Ilmu Penyakit Dalam. Ed 4. Pusat Penerbitan Ilmu Penyakit Dalam FK UI. Jakarta, 2006; 755-58.

2. Laffan M, Manning R. Investigation of haemostasis. In: Lewis SM, Bain BJ, Bates I eds. Dacie and Lewis Practical Haematology. $10^{\text {th }}$ ed. Philadelphia, Churchill Livingstone, 2003; 379-440.

3. Timan IS. Pitfalls Pemeriksaan Agregasi Trombosit. Dalam: Pendidikan Berkesinambungan Patologi Klinik. Jakarta, Bagian Patologi Klinik FK UI, 2006; 30-41.

4. Suharti C. Dasar-Dasar Hemostasis. Dalam: Sudoyo AW, Setiyohadi B, Alwi I, dkk. Ed. Buku Ajar Ilmu Penyakit Dalam. Ed 4. Jakarta, Pusat Penerbitan Ilmu Penyakit Dalam FK UI, 2006; 749-54.

5. Oesman F, Setiabudy RD. Fisiologi Hemostasis dan Fibrinolisis. Dalam: Setiabudy RD. Hemostasis dan Trombosis. Ed 3. Jakarta, Balai Penerbit FKUI, 2007; 1-8.

6. Setianto B. Sindroma Koroner Akut, Patofisiologi. Dalam: Diagnosa dan Tatalaksana Hipertensi, Sindroma Koroner Akut dan Gagal Jantung. Jakarta, Balai Penerbit RS Jantung Harapan Kita, 2001; 59-65.

7. Manurung D. Patogenesa terkini dari Sindroma Koroner Akut. Prosiding Simposium Pendekatan Holistik Penyakit Kardiovaskuler II. Jakarta, Balai Penerbit Bagian Ilmu Penyakit Dalam FK UI, 2003; 63-69.

8. Vorchheimer DA, Becker R. Platelets in Atherothrombosis. Mayo Clin Proc. 2006; 81(1): 59-68.

9. Marchant KK. Importance of platelets and platelet response in acute coronary syndromes. Cleveland Clinic Journal of Medicine. 2009; 76(1): 82-87.

10. Shantsila E. Watson T. Lip GYH. Laboratory Investigation of Platelets. In: Gresele P, Fuster V, Page JA. et al. Platelets in Hematologic and Cardiovascular Disorders. UK, Cambridge University Press, 2008; 128-131.

11. Mardiana I. Nilai Agregasi Trombosit pada Angina Tak Stabil dan Hubungannya dengan Faktor Risiko Utama Penyakit Jantung Koroner. Bagian Kardiologi FK UI/RSJHK. 2007.

12. Yoshida T, Hiroki T, Arakawa K. Platelet Aggregation Studies in Patients with Angina Pectoris. Japanese Circulation Journal, 1983; 47: 180-187.

13. Guha S, Sardar P, Karmakar R, et al. Dual Antiplatelet Therapy in ACS: Time-Dependent Variability in Platelet Aggregation During the First Week.

14. Hutajulu NC. Agregasi Trombosit Pada IMA. Bagian Kardiologi FK UI/RSJHK. 2007.

15. Lakhey M, Agarwal A, Badhe B. Platelet aggregometric study on whole blood of patients with ischaemic heart disease. Kathmandu University Medical Journal. 2005; 9(3): 11-16. 